\title{
SPECIAL ZONE FOR SHIP WASHING IN TRANSBOUNDARY MARINE POLLUTION REDUCTION AT MALAKA STRAIT
}

\author{
${ }^{1}$ Verdinand Robertua, ${ }^{2}$ Eunike Meliani Wahyuningtyas, \\ ${ }^{3}$ Bryan Libertho Karyoprawiro \\ 1,2,3 International Relations, Universitas Kristen Indonesia, Jakarta, Indonesia \\ ${ }^{1}$ verdinand.robertua@uki.ac.id, ${ }^{2}$ eunikemw@gmail.com, ${ }^{3}$ bryanlibertho@gmail.com
}

\begin{abstract}
The Malacca Strait, which has always been the world's most strategic trade route, has become the most frequently traversed by international ships. The potential for environmental pollution in the Malacca Strait is also enormous, especially pollution from ship waste in the form of liquid waste (water ballasts and hazardous toxic materials, or B3 liquid waste) and garbage from disposal during illegal ship washing. Bintan Island, which located close to the Malacca Strait, is one of the islands affected by foreign ship dumping, which avoids sanctions throughout Indonesia, such as Malaysia and Singapore, which require every incoming vessel to be clean of waste. Regulations made by the Singapore government regarding the inspection of the ships of each ship resulted in the act of washing boats in the Malacca Strait. Cleaning and washing tanks and vessels in inappropriate areas can result in environmental pollution caused by wastewater in the form of water, oil, and plastic waste that is very damaging to the environment. The establishment of an exclusive zone for ships carrying out ship cleaning activities as well as anchored anchor locations can reduce environmental damage in the Malacca Strait. This study uses a qualitative method using an ecological approach to see how ecological problems caused by ships cause cross-border issues that threaten ecosystems in the Malacca Strait, specifically the Bintan Islands conservation area. The data used in the form of qualitative data collected through document studies, interviews, document analysis, focused discussions, and field observations.
\end{abstract}

Keywords: Cross Border, Ship Waste, Malacca Strait, Bintan Island.

DOI: 10.33541/sp.v20i2.1548

Sociae Polites : Majalah Ilmiah Sosial Politik

Faculty of Social and Political Science, Universitas Kristen Indonesia

ISSN 1410-3745 print/ ISSN 2620-4975 online

Volume 20, Number 2 (July - December 2019)

Pages 115-126 


\section{Introduction}

\subsection{Background}

The sea has always been the main focus of human life and in the context of international relations. Historically, the contribution of the sea to social development can get made from at least four interdependent attributes. The sea is essential because of the resources it contains, uses as means of transportation and trade, as a means of exchanging information and its position as a source of strength and power (Till 2009). This role is even more significant because the sea is now a symbol of globalization for goods to be distributed, sold, and consumed throughout the world.

Indonesia, in this case, as an archipelago state, has a strategic geo position. Indonesia has the most extended coastline number two in the world with a length of $99,093 \mathrm{~km}$ with a presentation of two-thirds of Indonesia holds a vast natural resource potential and is very important for development in Indonesia (KKP 2018). Of course, if the growth in the marine and fisheries sector carried out optimally, it will improve the welfare of the community and guarantee the lives of future generations.

The position of the Malacca Strait is also the most critical area of sea lanes in the Southeast Asian Region. This 550 nautical mile area is one of the narrowest sea lanes, but thousands of ships from various countries pass each year. The Malacca Strait is one of the most important shipping lanes in the world, as famous as the Suez Canal or the Panama Canal. The Malacca Strait connects the Indian subcontinent with eastern and southeastern Asia and also across Europe (Sindo 2018). Although not included in the international strait category, the Strait of Malacca is recognized worldwide as a strait used in international shipping (channels used for global navigation) as stipulated in the 1982 United Nations Convention Law of the Sea (UNCLOS).

The condition of the Malacca Strait, which is $80 \%$ owned by Indonesia, is inseparable from problems with transport vessels that cross the Malacca Strait and want to enter Singapore as a transit port for international export commodities. Through the regulation 'Maritime \& Port Authority of Singapore No. 16 of 2008 Section 2 Paragraphs D \& E', it was stated that there is a requirement to physically clean the vessel and may only enter the Singapore area in a clean condition. This regulation causes many ships in their journey to the port of Singapore to wash boats and tankers at sea. They also dispose of engine cooling water and ship washing water into the sea, this term is called ballast water (IMO 2019). The ballast water discharged by these vessels contains oil and ship oil classified as waste. This activity carried out to avoid sanctions by the Singapore government.

According to the procedure, all cargo and vessel cleaning paths should get recorded in a logbook that is checked and controlled at each ship's descent or transit point by the port official. In this case, Indonesia was the most disadvantaged by oil spills and chemicals passing vessels.

Environmental pollution caused by ship waste is increasingly threatening Indonesian waters. Especially in the northern season, which lasts from October to February when the wind and sea currents lead to the Riau Islands. The massive amount of ships carrying out illegal dumping and washing activities, they consider Indonesian sea power as weak, or they have their calculation system related to wind movement and also an early detection system for the environmental pollution activities. The pattern of soil particles to move oil at the bottom of the sea surface gets driven by wind and ocean 
currents. When the winds are heading Indonesia, many incidents of pollution of marine ecosystems and also the habitat of marine animals around the Strait of Malacca are threatened (Gunadharma 2019).

The physical condition and chemical characteristics of polluted sea water will affect the ecosystem and marine biota in the Malacca Strait area due to increased marine pollution both from the mainland, dumping, and the ship's engine itself. For example, Bintan Island, which located around the Strait of Malacca, at least in the last decade, has become powerless to get shipments of waste oil that thought to have come from giant tankers in the Strait of Malacca. The Department of Maritime Affairs and Fisheries (DKP) of the Riau Islands Province reported that in 2016 the population of dugongs living in the Riau Islands was diminishing (BPSPL 2018).

One of the causes is sea pollution that occurs in the Malacca Strait. As a result, dugongs swim out of habitat, strayed, and stranded on the beach. According to the CTILIPI Core map, other marine biotas that must be protected because they threatened with extinction in the waters of the Regency of Bintan are dolphins, whale sharks, seahorses, clams, Lola, sea cucumbers, and napoleon fish. Besides, the islands in Bintan Regency are also the locations of habitat distribution for 3 of the seven species of turtles in the world, namely Green Turtles (Chelonia mydas), Hawksbill Turtles (Eretmochelys imbricata) and Lekang Turtles (Lepidochelys olivacae) (LIPI 2014).

Relating it to the Sustainable Development Goal no 14 on 'Life Below Water' and efforts in it to improve and maintain the quality of carrying capacity and preservation of the functions of the marine environment, and improve the lives of fishermen and coastal communities. It can conclude that petroleum waste spills will damage marine ecosystems, especially in coastal areas such as coral reef ecosystems, seagrass, and mangrove forests. The ecosystem is spawn and a place to find food for marine organisms. Damage to these ecosystems will result in the death of marine organisms such as coral, reef fish, algae, and seagrasses and will break the food chain in the sea. Furthermore, it will reduce primary productivity in the waters and ultimately will eliminate the livelihoods of people who depend on their lives in sea waters.

\subsection{Research Questions}

By seeing how dense the traffic of ships passing through the Malacca Strait as a result of the development of the world economy continues to develop, the condition and possibility of pollution in the Malacca Strait area are increasing due to the illegal dumping and washing activities that threaten Indonesia's marine ecosystem, especially in the Malacca Strait. From the perspective of the international political economy, it can see how economic growth will grow along with the level of environmental degradation9. Understanding how the anchor anchoring zones that temporarily used endanger marine animal habitats, the authors raised a study entitled "Zoning anchor anchoring locations and Shipwashing in Efforts to Reduce Transboundary Marine Pollution in the Malacca Strait."

Based on the description in the background and formulation of the problem above, authors formulated research questions need to be answered in this study:

- What is the condition of transboundary marine pollution that occurs in the Malacca Strait? 
- What are the implications of the rearrangement of anchor anchoring zones and ship washing for overcoming cross border issues in the Malacca Strait?

\subsection{Objectives and Purposes}

- This research intends to find out how environmental pollution occurs in the Malacca Strait, especially in the waters of Bintan Island,

- This research designed to find out how the implications of rearrangement of anchor anchoring zones and ship washing can reduce the potential for pollution of the marine environment.

\section{Research Method}

In carrying out this research, the authors use qualitative research methods in which this research will produce findings or results that are not numerical or statistical or other calculation results. A qualitative research method is a method used as a way to obtain answers from research relating to data in the form of narratives derived from interviews, observations and the results of extracting data from documents. A qualitative research method is a form of way in which researchers in collecting and analyzing data become part of the research process by participating with information providers.

The author uses a qualitative method approach to explore all corners of research as a whole and to be able to find variables that are relevant to the study conducted and see phenomena that occur comprehensively and comprehensively (Juliet and Strauss 2009). By using an environmental approach on how economic growth goes hand in hand with increased ecological degradation, this research conducted not only by collecting data but also the study that analyzed and reviewed every data collected.

The data used in this study divided into two categories, namely primary data and secondary data. Primary data is data in the form of the result of collecting data directly from someone related or documents. The primary data in this study are data obtained from interviews with Dr. Budhi Gunadharma and M. Saefudin Researchers at the Center for Marine Research at the Ministry of Maritime Affairs and Fisheries.

\section{Results and Discussion}

\subsection{Malacca Strait}

The Malacca Strait is a primary strategic gateway in the Asia Pacific region that connects Middle Eastern, African, and European countries through the Indian Ocean and the Atlantic Ocean to the Far East countries through the South China Sea and the Pacific Ocean. Ana G. Lopez, in his book International Straits: Concept Classification and Rules of Passage, reveals the international strait is (Saeri 2012, 809810):

"A natural waters area which becomes a crossing point, the international strait separates the two plains and connects between one seas off one coast country with another country's seas or between one Economic Zone. Exclusively (EEZ) with other EEZs with other countries' territorial seas, if 
possible, the international strait connects the inland waters of archipelago water used for international shipping."

Besides being considered an international strait, the Malacca Strait also viewed as the heart of global trade; this evidenced by 60,000 to 94,000 ships passing through the Malacca Strait each year. Among these ships are carrying $25 \%$ of world merchandise, 2/3 of the world's Liquefied Natural Gas (LNG), 14\% of daily world needs, and 11 million barrels of oil per day (Seconds 2018). Annual calculations also affect shipping patterns of sea transportation in the Malacca Strait. Through air pressure, the equator moves according to the position of the sun, crosses the equator twice in one year. In the dry season in the northern part of the world causes an area of low pressure to occur over the continent of Asia as a continuation of Equatorial air pressure.

Meanwhile, in winter as an area, one high pressure occurs over the Asian Continent, which is part of the subtropical high-pressure system. The monsoon occurs because there is a difference between the high winter climate in the North and the low pressure that occurs in other parts of the world. As a result of this pressure distribution stationary or fixed, the winds that work faster, change over the ocean.

The North Season in Southeast Asia runs from December to February, while the South season is from June to August. The rest of the year is the period between North and South seasons, and from the South to the North seasons (SeptemberNovember). Variations in air circulation positively affect changes in the water cycle in the ocean that are important to consider when discussing the problem of ocean pollution that is cross-border in nature. Imagine, the wind strongly influences the movement of the oil layer. Dependence can be estimated figures that the progress of the oil puddle is approximately 3 and 4 percent of the wind speed. At the same time, tidal currents also move the surface of the water and thus move the oil (Berger and Anderson, 1978, 6). So it is through the calculation of this season and its relation to what makes trade traffic via sea transportation crossing the Malacca Strait.

However, behind its strategic value from an economic point of view, the Malacca Strait also has cross-border sea environment problems between coastal countries in Southeast Asia, namely Indonesia, Malaysia, and Singapore, and is detrimental to strait-user countries. The potential for Malacca Strait pollution leads to severe ecosystem damage. The infection can occur due to oil spills, both originating from ship accidents (collisions and discharge of ballast water from these ships) such as the Showa Maru case in 1975. It estimated that 7,300 tons $(844,000)$ gallons of petroleum shed into the sea in the Malacca Strait and Singapore, which caused significant pollution in the waters of Singapore and Malaysia and Indonesia (Thambipilai and Saravamuttu 1985, 8).

\subsection{The International Convention for the Prevention of Pollution from Ships (MARPOL)}

The International Convention for the Prevention of Pollution from Ships, also known as MARPOL, is the primary reference in the handling of environmental pollution caused by ship operations and ship accidents that occur internationally. The MARPOL Convention began to be adopted by international maritime organizations in 1973 and has become a significant reference on handling the problem of marine 
pollution resulting from ship operations and accidents at sea. The MARPOL Convention has several scopes aimed at preventing and reducing the potential for marine pollution due to ship operations and disasters at sea. To date, the convention already has six technical ranges related to the issue, which also includes strict controls in several related functional areas (IMO 2019).

In cross-border environmental pollution problems that often occur in the Straits of Malacca, the coverage of the first, second, and fifth annex MARPOL conventions can be the primary reference in law enforcement and policymaking in the prevention of pollution. The environment occurs because most of the environmental pollution in the region comes from the operational activities of ships that sail across the Straits of Malacca.

In the first appendix, the MARPOL convention includes the prevention of pollution from oil outlines how pollution prevention can get carried out, including operational ship steps, prevention of oil disposal, as well as necessary activities of washing ships and tanks to prevent pollution at sea (IMO 2019). In the second annex of the MARPOL convention, it covered the scope of prevention and control of infection caused by large quantities of hazardous liquid. This second annex also regulates these hot liquid categories into four harmful liquid categories which, are discharged through the process of washing ships, tanks, or deballasting operations, which can endanger marine resources and human health. This annex explains what dangerous liquids are prohibited, controlled, and released for the use of vessel cleaning and deballasting, as well as the volume of fluid that can be used in the process (IMO 2019).

The fifth annex to the MARPOL convention includes efforts to prevent and reduce the amount of waste dumped into the sea from ships both directly and in the process of disposal of ships in the process of ship operations, ship washing, and tank tanks. In this annex, it has more to do with the placement of rubbish, such as food waste, residual waste from cargo, ship cleaning substances, and animal carcasses.

The scope of waste also includes all types of food, domestic and operational waste, all plastics, cargo residues, incinerator ash, cooking oil, fishing gear which produced during ships carrying out operational activities both in shipping and cleaning activities (IMO 2019).

The first, second, and fifth MARPOL annexes describe how each operational activity undertaken by the ship, especially in the process of cleaning the boat, must be carried out properly, and the waste generated from the operation of the vessels is not justified for careless disposal. Both liquids and rubbish made from ship operations can threaten the existing marine resources and endanger human health.

\subsection{Sea Pollution in the Malacca Strait}

Thousands of ships sailing in the Straits of Malacca, it is suspected that there is an element of intent from shipowners who carry out dumping activities by dumping waste from operational activities of ships into the sea. Waste disposal activities carried out by individual vessels can be carried out by disposing of, placing, and putting waste and materials in a certain amount, concentration, time, and location with different requirements to the environmental media in the form of the sea (London Dumping Convention 1972). Waste and other materials that are disposed of and potentially become marine trash are categorized, including potential contamination into categories that are essential references in determining whether a substance can get disposed of to 
the sea or not. Vessel waste categories include origin, total amount, shape, composition, properties, toxicity, waste presence, accumulation, and biotransformation of biological material and sentiments. Through this categorization can be taken as a reference for ship waste that can be disposed of to the sea or not so that it does not threaten and damage the existing marine environment ecosystem (IMO 2019).

A study conducted by Razak in 1989 reported that the concentration of heavy metals in the Malacca Strait experienced an increase in Mercury $(\mathrm{Hg})$ reaching 0.013 $\mathrm{ppm}$, lead $(\mathrm{Pb})$ from 0.035 to $0.060 \mathrm{ppm}$, cadmium $(\mathrm{Cd})$ from 0.009 to $0.014 \mathrm{ppm}$, Copper $(\mathrm{Cu})$ from 0.071 to $0.107 \mathrm{ppm}$. (Purwaka 1998, 54) Over the years, several incidents occurred in the Malacca Strait, which caused oil spills and ships to release oil and hazardous substances into the water, and in 2000, a study conducted.

The protection of the marine environment within the framework of international law is an accumulation of The Principle of National Sovereignty and The Freedom of High Se. The International Maritime Organization (IMO) states that "a right on the part of an estate threatened with the environmental injury from sources beyond its territorial jurisdiction, at least where those sources are located on the high seas, to take reasonable action to prevent or decrease that injury. "(IMO 1988, 2) The results of the field verification of the Riau Islands Province Environmental Agency in the 2017 KEMENKLHK Directorate General PSLB3 report suspect oil waste and various types of waste originating from cleaning tank vessels and other operational activities dumped in the international waters of the Malacca Strait (DPR RI 2018).

Moreover, through the Singapore government regulations in 'Maritime \& Port Authority Of Singapore Number 16 of 2008 article 2 Paragraph D \& E' requires physical cleaning of vessels (vessel \& tank cleaning) and may only enter Singapore in clean conditions. This regulation causes many ships in their journey to the port of Singapore to wash vessels and tankers at sea to avoid the imposition of sanctions from the port authority of Singapore (MPA 2018).

Vessels that carry out their operational activities in the Malacca Strait area also dispose of the remaining cooling water of the engine and the vessel's washing water into the sea, this term is called ballast water. The ballast water discharged by these vessels contains oil and ship oil, which classified as chemical waste, which is very dangerous and threatens the marine ecosystem in the Strait of Malacca.

As an effort to remove oil puddles above the sea and facilitate the washing of ships and tanks, illegal persons usually dissolve dispersants, which are chemicals to help break down large lumps of oil into smaller and spreading, making it easily digested by marine microbes. Of course, this is a chemical that remains dangerous because it spreads oil much more widely. The aim is to prevent oil spills from reaching the beach and smearing animals with smelly and sticky oils. Animals that inhabit the surface of the sea do benefit from a reduction in the oil layer. Still, animals that inhabit the deep sea and the seabed will experience more severe pollution.

\subsection{Bintan Island}

One of the islands in the Malacca Straits region, which is affected by environmental pollution, is Bintan Island. At least in the last decade, the island of Bintan has become powerless because it has received shipments of waste oil thought to have come from giant tankers in the Malacca Strait. Overall, the area of Bintan Regency reaches $88,038.54 \mathrm{~km}$, with a land area of only 2.21 percent or 
$1,946.13 \mathrm{~km}$, while the sea area reaches 97.79 percent or $86,092.41 \mathrm{~km}$ which is 240 islands (BPS 2018). The relatively sloping land topography, many river mouths, and bays make the coastal area of Bintan Regency has a complete coastal ecosystem. The mangrove ecosystem in Bintan Regency is unique. Compared to coral reefs and seagrasses, mangrove ecosystems are spread almost in all areas of the coastal sector (CRITC-P2O LIPI, 2014).

The Bintan Regency government realizes that the territorial waters of more than 97 percent must receive special attention. In 2009, through the Decree of the Regent of Bintan No. 58 / II / 2009, the Bintan Regional Water Conservation Area (KKPD) had been established, which has an area of 472,905 hectares. Data publication of the Ministry of Maritime Affairs and Fisheries states that until 2017, the total area of Marine Protected Areas in Indonesia has reached 19.14 million hectares spread over 172 regions. Riau Islands, as a whole, accounted for around 1.95 million hectares, or nearly 10 percent of the total area of water conservation areas in Indonesia.

The Bintan Sea, which is rich in natural resources, among others, has seagrass beds with relatively high species diversity, namely 10 of the 15 seagrass species found in Indonesia (Marwanto, 2017 in Hutomo and Nontji, 2014) and (P2O-LIPI, 2017). Seagrass beds in Bintan Island have an essential role for some endangered biota, such as the dugong (Dugong dugon), which uses seagrass as a portion of the leading food. However. The Department of Maritime Affairs and Fisheries (DKP) of the Riau Islands Province reported that in 2016 the population of dugongs living in the Riau Islands decreased. One of the causes is sea pollution that occurred in the Malacca Peninsula (KKP 2019).

\subsection{Recommendation of New Anchor Zone on Nipa Island}

Environmental pollution that occurs in the Malacca Strait area due to high ship traffic and illegal dumping and washing activities. The worsening pollution conditions require a logical and strategic solution. With the anchor zone for ships that want to dock and wash the vessels, it is regularly and can get monitored how the process of handling waste results from the operational activities of the ship. Potential pollution due to ship operations in the Malacca Strait area can get prevented so that the problem of environmental pollution will get reduced.

Nipa Island located in the Singapore Strait with an area of $+3600 \mathrm{~km} 2$. It has a base point of TD 190 and a reference point of TR 190 and has a navigation aid in the form of a $13 \mathrm{~m}$ lighthouse. The position of Nipa Island is very strategic and has economic potential because it located in a very dense marine traffic lane that requires supervision and proper use. Nipa Island can get used as a transit point for ships or temporary anchor zones for vessels crossing the Malacca Strait (KKP 2019). Nipa Island gets threatened due to abrasion, and the threat due to its location, which is the border between Indonesia and Singapore, requires proper supervision and utilization so that the island not wasted. The reclamation and development of the Nipa Island region have opened up the potential for further usage that can provide economic and environmental benefits.

The use of Nipa Island as a transit location for ships can overcome the problems of the marine environment due to the absence of a particular place where the vessels can carry out the ship and tank washing activities. Anchor anchoring zones built 
on Nipa Island require individual facilities to prevent potential pollution and control of ship operations such as ship washing, which can generate regional income. With the anchor landing zone created where ships can transit as well as washing ships and tanks before continuing shipping and entering Singapore, illegal vessel cleaning in the Malacca Strait can get reduced. In addition to benefits for the environment, economic and strategic advantages will get obtained by the use of Nipa Island.

\section{Conclusion}

Growing world economic growth has resulted in increasingly heavy ship traffic carrying various commodities passing through the Malacca Strait. Vessels that pass through the Malacca Strait sometimes carry out dumping activities and illegal vessel washing activities which produce hazardous wastes. The operational activities of ships carried out both legally and illegally in this area produce waste that has the potential for pollution and is very dangerous for the marine environment and human life. In international rules, as stated in MARPOL annex 1,2, and 5 as the wastes produced by ships are categorized and regulated how the processing of waste resulting from operational activities of boats should get done.

The operational activities of vessels in the Malacca Strait area should obey all existing regulations so that the potential for pollution of the marine environment can get prevented. However, with the economic impetus and avoidance of sanctions for ships wishing to enter Singapore as per the applicable rules in the territorial waters of Singapore. The vessel chose to carry out these dumping activities before they made a transit in Singapore, which eventually impacted on the environmental damage in the Malacca Strait region as occurred on Bintan Island. Lack of supervision and facilities for ships to transits while washing and disposing of waste from their operational activities properly and can be controlled, requires a policy of establishing anchor zones. The vessel later can carry out operations with excellent facilities and supervision so that environmental pollution can get reduced. Nipa Island is a strategic location for the construction of anchor zones and ship transit in the Malacca Strait. 


\section{BIBLIOGRAPHY}

\section{Books}

Berger dan Anderson. 1978. Modern Petroleum: A Basic Primer of the Industry. (Penn Well Books) page 6.

Corbin Juliet M, Strauss Anselm L, 2009, Basics Of Qualitative Research: Techniques And Procedures For Developing Grounded Theory, Los Angeles: Sage Publ, 2nd ed.

Till, Geoffrey. 2009. Seapower: A Guide for the Twenty-First Century, Second Edition, Routledge, New York.

Thambipilai \& Saravamuttu. 1985. ASEAN and The Law of SEA. Institute of Southeast Asia Studies, Singapore.Hal.8.

\section{Journals}

M. Saeri. Krakteristik dan Permasalahan Selat Malaka. Jurnal Transnasional, Vol 4. No. 2, Februari 2013.

Purwaka, Tomy, translator. 1998. Control of Marine Pollution in The Straits of Malacca and Singapore: Modalities for International Cooperation, Singapore Journal of International \& Comparative Law, page. 454..

\section{Documents}

International Maritime Organization. (IMO). 1988. Manual on Oil Pollution, Section II Contingency Planning, London, IMO, hlm2.

London Dumping Convention. 1972. Convention on the Prevention of Marine Pollution by Dumping of Wastes and Other Matter.

MPA Singapore. 2018. Post Marine Circular: Procedures to Control Tank Cleaning and Disposal of Sludge And Slop. Port Marine Circular.

POKJA Perbatasan, Draft Kerja Pengelolahan Perbatasan Laut, Kementrian Kelautan dan perikanan.

\section{Press Release}

The Secretary of State. 2019. "On the U.S. Withdrawal from the Paris Agreement." U.S. Department of State. 2019. https://www.state.gov/on-the-u-s-withdrawal-fromthe-paris-agreement/.

The White House. 2016. "President Obama: The United States Formally Enters the Paris Agreement." The White House. 2016. https://obamawhitehouse.archives.gov/blog/2016/09/03/president-obamaunited-states-formally-enters-paris-agreement.

United Nations Security Council. 2007. "Security Council Holds First-Ever Debate On Impact Of Climate Change On Peace, Security, Hearing Over 50 Speakers." United Nations Security Council. 2007. https://www.un.org/press/en/2007/sc9000.doc.htm.

Kedutaan Besar Amerika Serikat dan Konsulat di Indonesia. 2017. "Presiden Donald J. Trump Mengumumkan Strategi Keamanan Nasional Untuk Memajukan 
Kepentingan Amerika." Kedutaan Besar Amerika Serikat Dan Konsulat Di Indonesia. 2017. https://id.usembassy.gov/id/presiden-donald-j-trumpmengumumkan-strategi-keamanan-nasional-untuk-memajukan-kepentinganamerika/ (17/01/2020).

\section{Website}

Balai Pengelolaan Sumberdaya Pesisir dan Laut (BPSPL) Padang. 2018. Resume Habitat Dugong (Duyung) di Pulau Bintan Kepulauan Riau. Diakses melalui http://bpsplpadang.kkp.go.id/ pada tanggal 16 Oktober 2019.

Detiknews. 2018. Selat Malaka dan Potensi Industri Bioenergi Indonesia. Diakses melalui https://news.detik.com/kolom/d-4223947/selat-malaka-dan-potensiindustri-bioenergi-indonesia pada 17 Oktober 2019

Direktorat Jenderal Pengelolaan Ruang Laut. 2019. Dugong Terdampar mati di Sebong Pereh Kabupaten Bintai,. Diakses melalui https://kkp.go.id/djprl/artikel/8525dugong-terdampar-mati- di- sebong-pereh-kabupaten-bintan-25-januari-2019 pada 18 Oktober 2019

International Maritime Organization (IMO). 2009. Ballast Water Management. Diakses melalui

http://www.imo.org/en/OurWork/Environment/BallastWaterManagement/Pages /Default.aspx pada tanggal 16 Oktober 2019.

International Maritime Organization. (IMO). Marine Environment. Accessed http://www.imo.org/en/OurWork/Environment/Pages/Default.aspx pada 17 Oktober 2019

International Maritime Organization. (IMO).. MARPOL Annex 1: Prevention of Pollution by Oil. Accessed http://www.imo.org/en/OurWork/Environment/PollutionPrevention/OilPollutio n/Pages/Default.aspx pada 17 Oktober 2019.

International Maritime Organization. (IMO). Carriage of Chemicals by Ship. Accessed http://www.imo.org/en/OurWork/Environment/PollutionPrevention/ChemicalP ollution/Pages/Defa ult.aspx pada 17 Oktober 2019.

International Maritime Organization. (IMO). . Prevention of Pollution by Garbage from Ships. Accessed http://www.imo.org/en/OurWork/Environment/PollutionPrevention/Garbage/Pa ges/Default.aspx pada 17 Oktober 2019.

International Maritime Organization. (IMO) Report: Revised Specific Guidelines For The Assessment Of Vessels. Accessed http://www.imo.org/en/OurWork/Environment/LCLP/Publications/wag/Docum ents/2016\%20Rev\%20Specific\%20Guidelines\%20for\%20vessels.pdf\#search=v essel\%20waste pada 17 Oktober 2019.

Internasional Sindo News, "Jalur transportasi Air Paling Penting di Dunia". Diakses melalui https://international.sindonews.com/read/1289403/45/jalur-transportasiair-paling-penting-di- dunia-1520944003, pada tanggal 16 Oktober 2019.

Kementerian Kelautan dan Perikanan. (2018). Siaran Pers: Refleksi 2017 dan Outlook 2018 Membangun dan Menjaga Ekosistem Laut Indonesia. Diakses melalui https://kkp.go.id/djprl/artikel/2798-refleksi-2017-dan-outlook-2018membangun-dan-menjaga-

ekosistem-laut-indonesia-bersama-ditjen- 
pengelolaan-ruang-laut pada tanggal 16 Oktober 2019.

Laporan Kunjungan Kerja Spesifik Komisi VII DPR RI untuk Peninjauan Pengloahan Limbah B3 di Kota Batam, Masa Persidangan II 2018-2019 Diakses melalui http://www.dpr.go.id/dokakd/dokumen/K7-Laporan-Kunspek-Panja-Limbahdan-Lingkungan-ke- Batam-1547804641.pdf pada 17 Oktober 2019.

LIPI. 2014. Monitoring Kesehatan Terumbu Karang dan Ekosistem Terkait di Kabupaten Bintan. Diakses melalui http://coremap.oseanografi.lipi.go.id/berita/1153, pada tanggal 16 Oktober 2019.

Publikasi BPS Bintan. 2018. Kabupaten Bintan dalam Angka. Diakses melalui https://bintankab.bps.go.id/pada 17 Oktober 2019. 